\title{
L-leucin és lenalidomid együttes adásának kedvező hatása 5q- myelodysplasiás szindrómában
}

\author{
Szerafin László ${ }^{\circledR}$ Jakó János \\ Jósa András Oktatókórház, Hematológiai Osztály, Nyíregyháza
}

\begin{abstract}
Az 5q (del) genetikai eltéréssel bíró myelodysplasiás szindróma lenalidomid adásával hatékonyan kezelhető. Az L-leucin az mTOR szignálút gátlásával fokozza a haploinszufficiens riboszómális gének transzlációját és így szintén kedvező hatású lehet. Szerzők két betegük kórlefolyását ismertetik, akiket a két szer együttes adásával kezeltek. Első betegükben lenalidomidkezelés a transzfúziós igényt megszüntette, de az anaemia továbbra is fennállt, a gyógyszer adása súlyos leukopeniát és thrombocytopeniát okozott. A terápia L-leucinnal történő kiegészítése után a beteg vérképe gyorsan normalizálódott, elóbb a lenalidomid, majd az L-leucin is elhagyhatóvá vált, továbbiakban már az 5q (del) genetikai eltérés sem volt kimutatható, évek óta tartósan remisszióban van. Második betegükben az első szerként adott L-leucin szintén megszüntette a transzfúziós igényt, de az anaemiát nem. A terápia lenalidomiddal történő kiegészítése után a beteg vérképe gyorsan normalizálódott. A lenalidomid és L-leucin kombinációja - a két szer eltérő hatásmechanizmusa révén - egymás hatását fokozhatja és a terápiás eredményt tovább javíthatja. A kis esetszámú klinikai megfigyelések miatt még további vizsgálatok szükségesek.
\end{abstract}

Kulcsszavak: myelodysplasiás szindróma 5q (del), lenalidomid, L-leucin

\section{Beneficial effect of co-administration of L-leucine and lenalidomide in 5q-myelodysplastic syndrome}

The $5 \mathrm{q}$ (del) genetic myelodysplastic syndrome can be effectively treated by administering lenalidomide. By blocking the mTOR signaling pathway, L-leucine enhances the translation of haploinsufficient ribosomal genes and thus may also be beneficial. The authors report the course of disease of their two patients treated with the two agents. In their first patient, lenalidomide treatment abolished the need for transfusion, but anemia persisted, with severe leucopenia and thrombocytopenia. After adding L-leucine to the therapy, the patient's blood counts returned to normal rapidly, lenalidomide and then L-leucine were eliminated, and no genetic abnormality of $5 \mathrm{q}(\mathrm{del})$ was detected, and she is in remission for years. In their second patient, the first agent, L-leucine, also eliminated the need for transfusion, but not anemia. After the addition of lenalidomide therapy, the patient's blood counts returned to normal rapidly. The combination of lenalidomide and L-leucine - through the different mechanism of action of the two agents - may enhance each other's effects and further improve the therapeutic outcome. Due to the small number of clinical observations, further studies are required.

Keywords: myelodysplastic syndrome $5 \mathrm{q}$ (del), lenalidomide, L-leucine

(Beérkezett: 2020. febuár 7.; elfogadva: 2020. március 6.)

\section{Rövidítések}

CDC25C $=$ cell division cycle 25 homolog C; CK1 alpha $=$ case in kinase 1 alpha (enzim); CRBN-CRL4 E3 = cereblon - CRL4 E3 ubiquitin ligase enzym komplex; CSNK1A1 = casein kinase 1 alpha 1 (fehérjekódoló gén); MDM2 = murine double minute clone 2; 5q- MDS = myelodysplasiás szindróma 5q (del) genetikai eltéréssel; mRNS = hírvivő ribonukleinsav; $\mathrm{mTOR}=$ mammalian target of rapamycin; $\mathrm{PP} 2 \mathrm{Aca}=$ protein serine-threonine phosphatase type $2 \mathrm{~A}$ catalytic subunit $\alpha$; RPS = riboszómális fehérje S; SPARC = secreted protein, acidic, cysteine-rich (osteonectin/BM4D); TGF- $\beta=$ tumour growth factor- $\beta$

@ Levelezési cím: Dr. Szerafin László, Jósa András Oktatókórház, Hematológiai Osztály, 4400 Nyíregyháza, Szent István u. 68., Tel.: +3642599-700, E-mail: dr.szerafin.laszlo@szszbmk.hu 


\section{Bevezetés}

\section{$A z 5 q$ (del) szindróma ( $5 q-M D S)$ genetikai/ molekuláris háttere}

A myelodysplasiás szindrómát egy vagy több sejtrendszert érintő cytopenia jellemzi, amely a haemopoetikus őssejt klonális eltérése miatt jön létre. Az 5q- MDS a betegség egy viszonylag gyakran előforduló formája, amelyet macrocytás anaemia, <1\% blastarány, normális vagy emelkedett thrombocytaszám, hypolobulált magvú megakaryocyták, izolált 5q(del) genetikai eltérés jellemez [1]. A betegség genetikai hátterében több elváltozás áll:

- A riboszómális RPS14 gén haploinszuffficienciát okozó mutációja, ami az mRNS transzláció gátlását és következményesen az erythropoesis károsodását okozza [1-6].

- MikroRNS gének (mir-145, mir-146a) haploinszufficienciája. Ennek következménye a thrombocytosis, megakaryocyta dysplasia, enyhe neutropenia $[1,7,8]$.

- CSNK (casein kinase) $1 A 1$ gén (a CK1a-t, a $\beta$-katenin fó regulátorát kódolja) haploinszufficienciája (az esetek 7\%-ában). Emiatt a $\beta$-katenin (az őssejt-önmegújulás fő szabályozója) aktiválódik, ennek következménye a haemopoetikus őssejt klonális expanziója [1, 2, 9].

- P53-aktiváció. Hatására a betegség evolúciójának kockázata nő, a lenalidomidkezelés hatékonysága csökken $[1,6]$.

\section{Az 5q-MDS kezelése}

A transzfúziófüggő $5 q-$ MDS leghatékonyabb kezelése az immunmodulans hatású lenalidomid. Hatására az esetek 67\%-ában transzfúziómentesség, 45\%-ában pedig cytogenetikai remisszió alakul ki [1].

A lenalidomid hatásmechanizmusa:

- SPARC és aktivin A (TGF- $\beta$ család tagja) tumorszuppresszor gének túlszabályozása $\rightarrow$ anti-proliferatív, anti-adhezív, anti-angiogenetikus hatás $[1,10,11]$.

- PP2Aca és CDC25C haploinszufficiens foszfatázok gátlása, amelyek a sejtciklus G2/M átmenet együttes szabályozói. Következménye a sejtciklus G2 fázisának gátlása, apoptosis [1, 2, 12].

- P53 degradációjának elösegitése az MDM2 auto-ubiquitinatiójának gátlásával (MDM2 müködésének helyreállítása) [1, 2, 13].

- A CRBN-CRL4 E3 ubiquitin ligáz indukciója általi CSNK1A1 degradáció $[1,14]$.

A mir-145 mikroRNS indukciója korrelál a lenalidomidra adott klinikai válasszal és annak tartósságával [1].

A TP53-mutáció viszont negatív hatású a lenalidomidkezelés eredményességére [1].

Lenalidomid hatására az átlagos túlélés is javul, és az akut leukémiás átalakulás is csekély. Nem $5 q$ - MDS-ben is a kis kockázatú betegek $26 \%$-a transzfúziómentessé válhat. Azonban nem minden 5q- MDS-s beteg reagál a lenalido- midra, és kb. felükben 2-3 éven belül rezisztencia alakul ki [1]. Ezért szükséges újabb terápiás lehetőségek keresése.

5q- MDS-ben károsodott a riboszóma biogenezis. Számos riboszómális és transzlációt szabályozó gén deregulálódik. Az L-leucin guanizil trifoszfatázokhoz kötödik, és azok aktiválása révén az mTOR szignálút aktivációjával fokozza a transzlációt, ami az anaemia mérséklödéséhez vezet [1, 3-5]. Ezt in vitro vizsgálatok [1, 3, 4, 15-17], állatkísérletes modellek [1, 3, 5, 6, 15, 18, 19] és szórványos klinikai esetbemutatások is alátámasztják DiamondBlackfan-szindrómában [20] és az ezzel genetikailag rokon 5q-MDS betegségben (riboszomapathiák) [21, 22]. Az L-leucin elágazó láncú esszenciális aminosav, amelynek kiemelt jelentősége van az izommüködésben, emiatt testépítők gyakran használják táplálék-kiegészítőként. Számos készítmény van forgalomban por vagy kapszula alakjában, viszonylag olcsó, könnyen hozzáférhető. Fontos azonban kiemelni, hogy széles körü klinikai vizsgálatok eredményei nem állnak rendelkezésre ezzel a hatóanyaggal kapcsolatban. Egyéb terápiás lehetőség is vizsgálat tárgya, mint a Cenersen. Ez egy antisense oligonukleotid, amely gátolja a p53-expressziót és helyreállítja az erythropoesist. Alacsony rizikójú MDS-ben klinikai vizsgálatok a szerrel még folyamatban vannak [1]. A p53 antagonista hatású Dexamethason lenalidomiddal együtt adva nyolcból öt lenalidomidrezisztenssé vált betegben transzfúziómentességet eredményezett és a p53-expreszszió csökkent [1]. Szerzők két betegük kórlefolyását ismertetik, akiket lenalidomid-, illetve L-leucin-kezelésben részesítettek első vonalban, de a nem kielégítő hatás miatt később azt a másik szerrel kombinálták, és a két szer együttes adásának hatására vérképük normalizálódott, egyiküknél már tartós komplett genetikai remisszió is kialakult.

\section{Esetismertetés}

1. beteg: 61 éves nő. Anamnézisében hypothyreosis, hyperlipidaemia, enyhe fokú, nem inzulinfüggő diabetes mellitus, mérsékelt vesefunkció-beszükülés szerepel. Fokozódó nagy transzfúziós igényü anaemia (6-4 hetente 3-4 E vörösvértest), transzfúziós haemosiderosis miatt került felvételre osztályunkra. 2011 novemberében a csontvelő morfológiai vizsgálata erythroid hypoplasiát, megakaryocyta dysplasiát mutatott. Cytogenetikai, FISHvizsgálat 5q- szindrómát igazolt (71\%). Napi $10 \mathrm{mg}$ lenalidomid adását kezdtük el, havonta 21 napos ciklusokban. 2012 augusztusára transzfúziós igénye tartósan megszünt, de hemoglobinszintje (hgb) maximum 86 g/l-ig emelkedett, súlyos thrombocytopenia, leukopenia alakult ki, utóbbi miatt ínhüvelygyulladás lépett fel, ezért a jobb kéz V. ujj amputatiója vált szükségessé. Emiatt 2012 októberében a lenalidomid dózisát másnaponta 10 mg-ra csökkentettük, és a beteg tájékoztatását, beleegyezését követően napi $15 \mathrm{~g}$ L-leucin-tartalmú étrend-kiegészítő por szedését is elkezdte. 2012 decemberétől FISH-vizsgálattal 
az 5q deléció már nem mutatható ki. 2013 januárjában hgb $98 \mathrm{~g}$ /l-re emelkedett, a lenalidomid szedését abbahagyta a továbbra is súlyos fokú thrombocytopenia miatt, az $5 \mathrm{q}$ (del) vizsgálat negativitásának ismeretében. Újabb négy hónap múlva a hgb már 109 g/l-re emelkedett, akkor az L-leucin szedését is abbahagyta. 2013 szeptemberére hgb, fehérvérsejtszám normalizálódott, thrombocytaszám is tovább javult, tartósan $100 \mathrm{G} / \mathrm{l}$ érték fölé emelkedett. 5q (del) genetikai eltérés azóta sem volt kimutatható, deferazirox adására haemosiderosisa is megszúnt. L-leucin szedése közben mellékhatást nem jelzett. A beteg hgb-szintjének változását az 1. ábrán mutatjuk be.

2. beteg: 52 éves nő. Anamnesisében a jobb lábszár mélyvénás thrombosisa, 2016-ban diagnosztizált anaemia perniciosa (B12-vitamin-pótlás hatására vérképe normalizálódott), axialis hiatus hernia, gastrooesophagealis reflux (2017), nem inzulinfüggő diabetes mellitus (2017) szerepel.
2018 áprilisában hgb-szintje váratlanul 69 g/l-re csökkent, emiatt más intézményben transzfundálták (vitamin B12, folsavszint normális, ferritinszint emelkedett volt). 2018 júniusában $73 \mathrm{~g} / \mathrm{l}$-es hgb-érték miatt ismét transzfúzióra szorult. Ezt követően irányították hematológiai szakrendelésünkre. A csontvelő morfológiai vizsgálata során dysplasiás vonások voltak láthatók, áramláscytometriával csak enyhe immunfenotípus-eltéréseket mutattak ki, 20\%-os reaktív lymphocytosissal. Cytogenetikai vizsgálat viszont inv(2) és $5 \mathrm{q}$ deléciót eredményező $\mathrm{t}(2 ; 5)$ transzlokációt igazolt. 2018 júliusában (hgb $84 \mathrm{~g} / \mathrm{l}$ ) $5 \mathrm{~g} /$ die L-leucin por szedését kezdte el. Azóta újabb transzfúzióra már nem volt szüksége. 2018 decemberében a hgb 93 g/l-re emelkedett, az L-leucin-dózisát napi $2 \times 5$ g-ra emeltük. 2019. június - júliusban a hgb $74 \mathrm{~g} / \mathrm{l}$-re csökkent, ezért az L-leucin mellett napi $10 \mathrm{mg}$ lenalidomid szedését is elkezdte (21 nap/hó ciklusokban). 2019 októberétől a hgb-szint ismét fokozatosan emelkedett, 2020 januárjában már 116 g/l volt, a fehérvérsejt-,

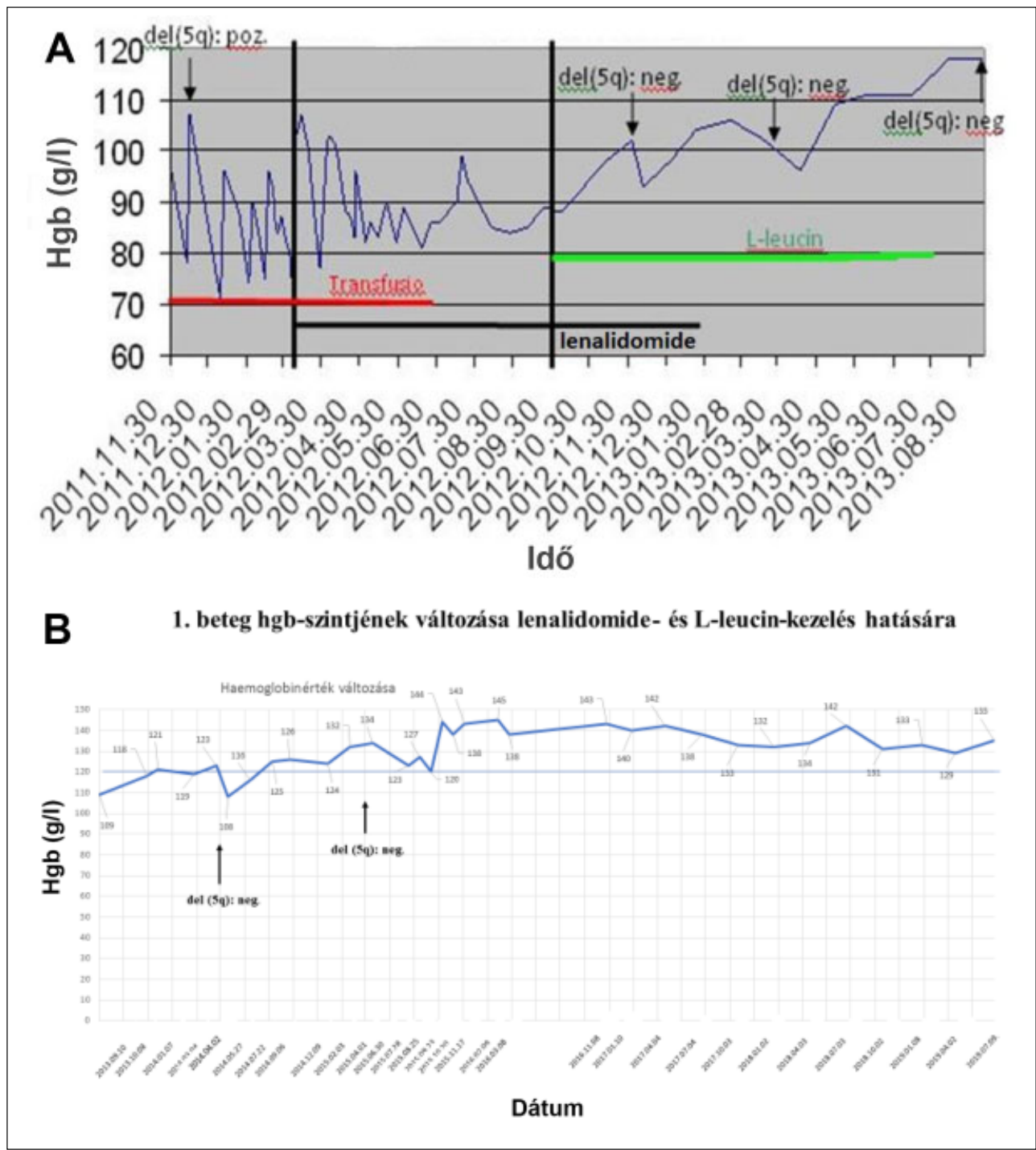

1. ábra. Első betegünk hgb-szintjének változása a lenalidomid + L-leucin-kezelés során 


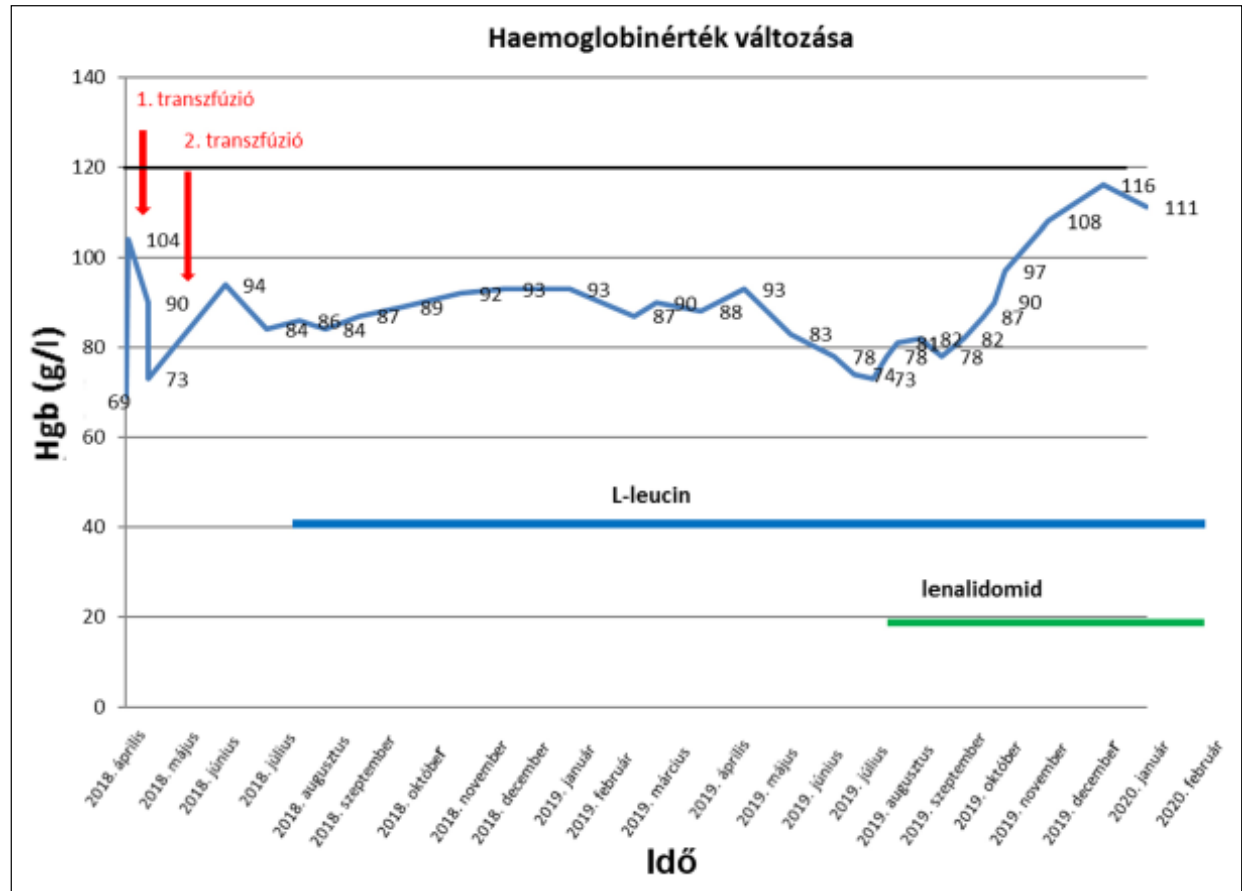

2. ábra. Második betegünk hgb-szintjének változása az L-leucin + lenalidomid-kezelés során

thrombocytaszáma normális. Második betegünk hgbszintjének alakulását a 2. ábrán mutatjuk be.

\section{Megbeszélés}

Az 5q- MDS viszonylag jó prognózisú betegség. Genetikai háttere mára már kellően tisztázott [1]. Kezelésében $a z$ első választandó gyógyszer a lenalidomid, amelynek hatására az esetek kb. 67\%-ában transzfúziómentesség érhető el, és a cytogenetikai remisszió aránya is jelentős [1]. A lenalidomid szedését - mellékhatások hiányában - a progresszió jelentkezéséig javasolják folytatni. Az L-leucin aminosav az mTOR szignálút aktivációja révén fokozza az mRNS transzlációját [1, 3-6, 15-17], így elvileg kedvező hatású lehet mindkét - 5q- MDS és Diamond-Blackfan - betegség esetében, csökkentheti az anaemia mértékét. A klinikai adatok azonban csak igen szórványosak. Diamond-Blackfan-anaemiában Pospisilova és mtsai számoltak be egy négyéves gyermek anaemiájának jelentős csökkenéséről napi $2 \times 500 \mathrm{mg}$ L-leucin adása hatására. A dózist a L-leucin abszorpciós görbéje alapján állapították meg [20]. Mi is ezt a dózist vettük alapul testfelszínre átszámítva az első betegünknél, majd a második betegünknél is hasonló dózisra emeltük. További vizsgálatok esetén ezt a dózismeghatározást javasolnánk kiinduló pontként. 5qMDS-ben Steensma és mtsai három, tartósan transzfúzióra szoruló, erythropoesist stimuláló gyógyszerre nem reagáló betegüknek $3 \times 1500 \mathrm{mg}$ dózisban adtak L-leucin kapszulát. Mellékhatást nem észleltek, de a transzfúziós igény nem szűnt meg [21]. Ito és mtsai hetente három alkalommal $2 \times 1,8 \mathrm{~g}$ L-leucin-kezelést alkalmaztak 8 qq- MDS be- tegüknél. A kezelés hatását 8-12 hét múlva értékelték. Nyolcból hat esetben (75\%) az abszolút reticulocytaszám javulását tapasztalták, de csak egy betegükben javult a hgb-szint. Súlyos mellékhatást nem tapasztaltak [22]. Mi az első betegünknél kezdetben lenalidomidot adtunk, anaemiája mérséklődött, de nem szünt meg, viszont transzfúzióra a továbbiakban már nem szorult. A hematológiai mellékhatások miatt döntöttünk az L-leucin hozzáadása mellett, amely eredményesnek bizonyult. Előbb a lenalidomid, majd az L-leucin is elhagyhatóvá vált, hgb-szintje tartósan normalizálódott, évek óta teljes cytogenetikai remisszióban van.

Második betegünknél első kezelésként alkalmaztuk az L-leucint emelkedő dózisban, amelynek hatására szintén transzfúziómentessé vált, de az anaemia ez esetben sem szünt meg, ami közérzetét befolyásolta. Esetében második kezelésként alkalmaztuk a lenalidomidot, amelynek hatására hgb-szintje fokozatosan tovább emelkedett, panaszmentessé vált. Újabb cytogenetikai vizsgálatát is tervezzük.

Két betegünk kórtörténete arra utalhat, hogy - bár önmagában az L-leucin-kezelés nem elegendő, és egyes esetekben a lenalidomid sem eredményez teljes remissziót a két terápia együttes alkalmazása hatékonyabb lehet, mint külön-külön adásuk. Az L-leucin olcsó, könnyen hozzáférhető (nem gyógyszer!). Alkalmazásakor azonban több, fokozottan hangsúlyozandó megválaszolandó kérdés merül fel:

1. Hogyan választhatók ki azok a betegek, akiknél az L-leucin hatásos lehet? (Ebben segíthet a bazális és post-leucin transzlációs szint mérése [1,20], azonban ez a klinikai gyakorlatban nem kivitelezhető). 
2. Mi az L-leucin optimális dózisa? (A leucin abszorpciós teszt segítség lehet [20], de nem rutinvizsgálat)

3. Az L-leucin adagolásának időtartama? Tapasztalatok, hosszú távú tervezett vizsgálatok hiányában az L-leucin adásának időtartamáról nem lehet nyilatkozni. Valószínúleg a lenalidomidhoz hasonlóan folyamatosan kell adni, hiszen a két szer kombinációjától várható a hatás fokozódása. Ez alól a tartós komplett genetikai remisszió lehet kivétel.

4. Esetleges késői mellékhatások? Az mTOR aktivációja anabolikus hatást fejt ki, növeli az izomtömeget, javítja a fizikai teljesítőképességet, növeli az inzulin- és csökkenti a vércukorszintet. Az L-leucin nagy dózisban elvileg emelheti a vérben az ammóniaszintet, krónikus fáradtságot, csökkent koordinációs készséget okozhat. Csökkentheti a szerotonin neurotranszmitter aktivitását, így hatással lehet a hangulatra. A B3és B6-vitaminok szintézisének csökkentésével súlyosbíthatja a pellagra és a jávorszirup-betegség tüneteit. Ezekkel azonban sem az irodalomban, sem saját betegeinknél nem találkoztunk. A leucinfogyasztás felsô határa nincs megadva, de a bevitelt $500 \mathrm{mg} /$ testsúlykilogrammra javasolják korlátozni a forgalmazók. Betegeink ennél jóval kisebb dózisban szedték az L-leucint.

5. Az L-leucin-készítmények hatóanyag-tartalmának, tisztaságának garantálása? (A terméket forgalmazók erről általában nyilatkoznak, de az L-leucin nem gyógyszer, az azokra vonatkozó különleges előírások nem kötelezőek rájuk nézve).

6. Nincsenek nagy esetszámú klinikai vizsgálatok.

A lenalidomid és L-leucin különbözö hatásmechanizmusuk révén kiegészithetik és fokozhatják egymás hatását, ezért kombinált adásuk 5q-MDS-ben figyelmet érdemel. Ennek megerösitéséhez további vizsgálatok szükségesek. Mivel azonban hosszú távú, randomizált klinikai vizsgálatok eredményei jelenleg még nem állnak rendelkezésre, ezért esetismertetésünk csupán a figyelem felkeltést szolgálhatja.

Nyilatkozat: A közlemény más folyóiratban korábban nem jelent meg és máshová beküldésre nem került. A levelező szerző a szerzői útmutatót elolvasta.

Érdekeltségek: A szerzőknek nincsenek érdekeltségeik.

Anyagi támogatás: A közlemény elkészítéséhez a szerzők anyagi támogatásban nem részesültek.

Szerzői munkamegosztás: Sz.L. - témafelvetés, irodalomgyüjtés, a közlemény megírása; J.J. - a közlemény megírása. A cikk végleges változatát valamennyi szerző elolvasta és jóváhagyta.

\section{Irodalom}

[1] Pellagatti A, Boultwood J. Recent advances in the 5q- syndrome. Mediterr J Hematol Infect Dis. 2015; 20(7): e2015037.
[2] Padron E, Komrokji RS, List AF. Biology and treatment of the 5q- syndrome. Expert Rev Hematol. 2011; 4: 61-69.

[3] Boultwood J, Yip BH, Vuppusetty C, et al. Activation of the mTOR pathway by the amino acid (L)-leucine in the 5q- syndrome and other ribosomopathies. Adv Biol Regul. 2013; 53: 8-17.

[4] Yip BH, Vuppusetty C, Attwood M, et al. Activation of the mTOR signaling pathway by L-leucine in 5q- syndrome and other RPS14-deficient erythroblasts. Leukemia 2013; 27: 1760-1763.

[5] Narla A, Payne EM, Abayasekara N, et al. L-Leucine improves the anaemia in models of Diamond-Blackfan anaemia and the 5q- syndrome in a TP53-independent way. Br J Haematol. 2014; 167: 524-528.

[6] Ear J, Hsueh J, Nguyen M, et al. A zebrafish model of 5-q syndrome using CRISPR/Cas9 targeting RPS14 reveals a p53-independent and p53-dependent mechanism of erythroid failure. J Genet Genomics 2019; 43: 307-318.

[7] Starczynowski DT, Kuchenbauer F, Argiropoulos B, et al. Identificiation of miR-145 an miR-146a as mediators of the 5q- syndrome phenotype. Nat Med. 2010; 16: 49-58.

[8] Kumar MS, Narla A, Nonami A, et al. Coordinate loss of a microRNA and protein-coding gene cooperate in the pathogenesis of 5q- syndrome. Blood 2011; 118: 4666-4673.

[9] Schneider RK, Adema V, Heckl D, et al. Role of casein kinase 1A1 in the biology and targeted therapy of del (5q) MDS. Cancer Cell 2014; 26: 509-520.

[10] Pellagatti A, Jadersten M, Forsblom AM, et al. Lenalidomide inhibits the malignant clone and up-regulates, the SPARC gene mapping to the commonly deleted region in 5q- syndrome patients. Proc Natl Acad Sci USA 2007; 104: 11406-11411.

[11] Komrokji RS, List AF. Role of lenalidomide in the treatment of myelodysplastic syndromes. Semin Oncol. 2011; 38: 648-657.

[12] Wei S, Chen X, Rocha K, et al. A critical role of phosphatase haplodeficiency in the selective suppression of deletion 5q MDS by lenalidomide. Proc Natl Acad Sci USA 2009; 106: 12974-12979.

[13] Wei S, Chen X, McGraw K, et al. Lenalidomide promotes p53 degradation by inhibiting MDM2 auto-ubiquitination in myelodyslastic syndrome with chromosome 5 q deletion. Oncogene 2013; 32: $1110-1120$.

[14] Fink EC, Krönke J, Hurst SN, et al. Lenalidomide induces ubiquitination and degradation of CSNK1A1 in MDS with $\operatorname{del}(5 q)$. Blood 2014; 124: 4. (In: 56th ASH Annual Meeting Abstracts.)

[15] Payne EM, Virgilio M, Narla A, et al. L-Leucine improves the anemia and developmental defects associated with Diamond-Blackfan anemia and del(5q) MDS by activating the mTOR pathway. Blood 2012; 120: 2214-2224.

[16] Yip BH, Pellagatti A, Vuppusetty C, et al. Effects of L-leucine in $5 \mathrm{q}$ - syndrome and other RPS14-deficient erythroblasts. Leukemia 2012; 26: 2154-2158.

[17] Bello E, Kerry J, Singh S, Yip BH, et al. L-leucine increases translation of RPS14 and LARP1 in erythroblasts from del(5q) myelodysplastic syndrome patients. Haematologica 2018; 103: e496e500.

[18] Jaako P, Debnath S, Olsson K, et al. Dietary L-leucine improves the anemia in a mouse model for Diamond-Blackfan anemia. Blood 2012; 120: 2225-2228.

[19] Kamimae-Lanning AN, Kurre P. L-Leucine alleviates DiamondBlackfan anemia. Blood 2012; 120: 2157-2158.

[20] Pospisilova D, Cmejlova J, Hak J, et al. Successful treatment of a Diamond-Blackfan anemia patient with amino acid leucine. Haematologica 2007; 92: e66-e67.

[21] Steensma DP, Ebert BL. Initial experience with L-leucine therapy in myelodysplastic syndromes with associated chromosome $5 \mathrm{q}$ deletion. Blood 2013; 121: 4428.

[22] Ito K, Hayashi T, Inaguma Y, et al. Effect of L-leucine therapy on hematopoietic function in elderly myelodysplastic syndrome patients. Biol Pharm Bull. 2019; 42: 1651-1657. 


\section{ESETISMERTETÉS}

[23] Draptchinskaia N, Gustavson P, Andersson B, et al. The gene encoding ribosomal protein S19 is mutated Diamond-Blackfan anaemia. Nat Genet. 1999; 21: 169-175.
[24] Zhang Y, Ear J, Yang Z, et al. Defects of protein production in erythroid cells revealed in a zebrafish Diamond-Blackfan anemia model for mutation in RPS19. Cell Death Dis. 2014; 5: e1352.

A cikk a Creative Commons Attribution 4.0 International License (https://creativecommons.org/licenses/by/4.0/) feltételei szerint publikált Open Access közlemény, melynek szellemében a cikk bármilyen médiumban szabadon felhasználható, megosztható és újraközölhető, feltéve, hogy az eredeti szerző és a közlés helye, illetve a CC License linkje és az esetlegesen végrehajtott módosítások feltüntetésre kerülnek. (SID_1) 